PASTORAL VOCACIONAL CONTEXTUAL Y CORRESPONSABLE

Autor: Urbano Sánchez García. Sacerdote Operario actualmente Director Espiritual en el Seminario de Almería.

\title{
DOI: https://doi.org/10.52039/seminarios.v53i163.915
}

Entre los enfoques que admite la Pastoral vocacional está el contextual, fundamentado en la Teología de la misma denominación y que se puede analizar en tres áreas: la histórico-cultural, la de evangelización y la eclesial.

\section{$1^{\circ}$ EL CONTEXTO CULTURAL-HISTÓRICO}

Con el fundamento de la Teología contextual esta primera parte describe algunos de los rasgos culturales y personales que identifican al joven, posible candidato para el sacerdocio diocesano.

\section{Punto de partida: Teología contextual y Pastoral vocacional}

La Teología contextual reflexiona sobre el mensaje cristiano teniendo en cuenta la situación vital, social y cultural del tiempo y del 
lugar en que es elaborado. Este enfoque teológico recoge la sensibilidad del momento, lee los signos de los tiempos e intenta responder a los problemas que hay que afrontar en el ámbito de la Iglesia o en la sociedad. Es cometido también dar un significado a la historia concreta, a la cultura de los destinatarios del anuncio cristiano y a las inquietudes y preocupaciones personales o sociales. Esto significa que no es posible hacer la misma teología en Europa que en Asia, a finales del $\mathrm{XX}$ que en los primeros años. Requiere, por lo tanto, una buena información del contexto que puede recogerse con los medios de comunicación social1 ${ }^{1}$.

El porqué de una Pastoral vocacional contextual. El Instrumento de trabajo de la Comisión episcopal de seminarios y universidades sobre Pastoral vocacional de la Iglesia en España, da una definición de Pastoral vocacional y hace ver su rasgo contextual. La definición de Pastoral vocacional pertenece al I Congreso internacional sobre las vocaciones, documento conclusivo, (1973). Dice así: la Pastoral vocacional es «aquella específica y compleja actividad de la comunidad eclesial por la que, en íntima unión con la pastoral general y como factor integrante de la misma, se compromete en la tarea de suscitar, acoger, acompañar y proporcionar la adecuada formación a las vocaciones de especial consagración» ${ }^{2}$. Y a continuación subraya la diferencia entre Pastoral vocacional y los otros tipos de pastoral como la Pastoral de juventud, Pastoral familiar, etc.. ¿Dónde esta lo contextual? En que la Pastoral vocacional posee "también una dimensión de toda acción pastoral que debe estar presente en toda la dedicación pastoral; catequética, educativa, litúrgica, de juventud e infancia, familiar, obrera, de enfermos, etc..." 3 .

De lo anterior se puede concluir: la Pastoral vocacional se entiende en el contexto (dentro de) de otras acciones pastorales con las respectivas situaciones que afrontan. La Pastoral Vocacional, por tanto,

1 OVIEDO, L., Teología contextual. Art. en Diccionario teológico enciclopédico, Verbo Divino, Estella 1995 y CHAPPIN, M., Teología en contexto, en DTF, 1497-1503: METZ, J.B., La fe en la Historia y en la sociedad, Cristiandad, Madrid 1979.

2 COMISIÓN EPISCOPAL DE SEMINARIOS Y UNIVERSIDADES Instrumento de trabajo sobre Pastoral vocacional de la Iglesia en España, EDICE, Madrid 1988, 30 La definición está en el n.5

3 Dc. pg. 20. 
comprende la ayuda que la Iglesia ofrece a sus miembros más jóvenes en orden a capacitarlos para poder llegar a la elección de vida en ella, entendida la elección de vida como el acto de opción fundamental 4.

La Pastoral vocacional de signo contextual analiza, ante todo, los rasgos culturales y sociales en los que se desenvuelve hoy día el posible candidato al sacerdocio. Una segunda tarea complementaria radica en el análisis del modo de pensar, sentir y obrar del joven de nuestros días (su cultura). El primer fruto de la tarea realizada consistirá en presentar para todo educador una serie de objetivos y desafíos a tener presentes.

El promotor vocacional tiene aquí un primer objetivo para su tarea que puede plantearse en varios interrogantes: ¿cómo son los jóvenes a los que deseo presentar la oferta vocacional? ¿cuál es su mentalidad y motivaciones, cuáles son sus problemas ante lo vocacional en general, qué dificultades y qué objeciones presentarán?

\section{El contexto cultural condiciona la vocación}

Presentamos algunos rasgos más elementales de la cultura en general para hablar de la cultura actual.

a) La cultura en general. De siempre la cultura ha sido un factor que favoreció o dificultó la vocación al sacerdocio. La cultura en su perspectiva ético-social une a hombres y naciones, es reflejada en la psicología del yo humano (mentalidad y conducta), incluye como expresión importante la religiosidad de los pueblos y a su vez actúa como factor condicionante de las relaciones del hombre con la divinidad 5 .

${ }^{4}$ Dc. pg. 20.

${ }^{5}$ Bibliografía sobre cultura: AA.VV., Evangelizar la cultura, PPC, Madrid 1978. F. BOAS, Cuestiones fundamentales de antropología cultural, Buenos Aires 1964. J. CHEVALIER, Historia del pensamiento. El pensamiento moderno, Aguilar, Madrid 1964. E.CHIAVACCI, Cultura. Artículo en Diccionario teológico interdisciplinar, Sígueme, Salamanca 1982. J. C. ESLIN, Cultura, en Iniciación a la práctica de la teología, V. Cristiandad, Madrid 1986,135-181. H. MARCUSE, Cultura y sociedad, Buenos Aires 1967. J. M. ROVIRA I BELLOSO Fe y cultura en nuestro tiempo, Sal Terrae, Santander 1988. R. SCHERER, Cultura. Artículo en Sacramentum Mundi. Enciclopedia teológica, oc. CELAM: SANTO DOMINGO, Nueva evangelización, promoción humana, cultura cristiana. IV Conferencia general del Episcopado latinoamericano, 1992. C. TULLIO-ALTAN, Manuale di antropologia culturale, Milano 1971. VATICANO II, Documentos, 1965. 
Dentro del objetivo de ese artículo destacamos el aspecto relacional que subraya el Documento de Puebla siguiendo el pensamiento de la Gaudium et Spes. La cultura viene a ser "el modo particular como, en un pueblo, los hombres cultivan su relación con la naturaleza, entre sí mismos y con Dios (GS 53b), de modo que puedan llegar a "un nivel verdadera y plenamente humano" (GS 53a) 6. "La cultura así entendida, abarca la totalidad de la vida de un pueblo, el conjunto de valores que lo animan y de desvalores que lo debilitan"... "comprende las costumbres, la lengua, las instituciones y estructuras de convivencia social" (Puebla, n.387). Luego con la palabra cultura se incluyen las actividades y creaciones humanas en el orden económico, artístico, ético, legal, religioso, espiritual, social, etc.

En la perspectiva sociológica el hombre aparece como receptor de la cultura que predomina en su geografía e historia más concretas. La cultura es tomada, como el conjunto de datos del ambiente humano en el que se encuentra inserto y por el que está igualmente condicionado. Esos datos son el lenguaje, las costumbres, el patrimonio artístico, las estructuras sociales y reproductivas, los métodos educativos, la organización de la producción, etc. La cultura constituye un ambiente histórico determinado en el cual se inserta el hombre de cada nación o de cada época y del que recibe los valores para promover la civilización humana.

Toda cultura incluye un proceso histórico-dinámico con varias fases: puede ser entendida como humanización que es la suprema meta del hombre y de la humanidad; como desnaturalización puesto que el hombre es naturaleza e historia; como liberación por su proceso de perfeccionamiento; y como solidaridad puesto que la cultura pertenece al ser y no al tener del hombre. Según Puebla "la cultura es una realidad histórica y social" (392), que está sometida a un proceso de cambio permanente según los nuevos valores o desvalores que surgen en la historia (393).

Como conclusión, y con la autoridad del Vaticano II, la cultura viene a ser la "distinta manera de servirse de las cosas, de trabajar, de expresarse, de practicar la religión, de comportarse, de establecer leyes e instituciones jurídicas, de desarrollar las ciencias, las artes y de cultivar la belleza" (GS 53).

6 CELAM: PUEBLA, La evangelización en el presente y en el futuro de América Latina, Trípode, Caracas 1979,30. n.387. 
b) Algunos rasgos ético-religiosos de la cultura actual europea. Imposible una descripción completa. Me quedo solamente con algunos de los rasgos que están más relacionados con la ética y con la fe que condicionan y hasta bloquean la vocación en sí misma y la tarea del promotor vocacional.

En nuestro mundo de la postmodernidad predomina el secularismo que da lugar al eclipsamiento de los valores espirituales y morales. La crisis de vocaciones de las últimas décadas, de la que salimos lentamente, es síntoma de una crisis más profunda en la vivencia de los valores religiosos y de los valores humanos. Hoy se exalta el pragmatismo, la autonomía de la persona, las libertades, la capacidad de autorrealización, los humanismos reduccionistas, los atractivos de la sociedad del bienestar materialista y cierta tergiversación de la sexualidad humana (Cf. PD 7).

En el Sínodo para Europa de 1999, el grupo hispano-luso, representado por el relator Monseñor Uriarte, entonces obispo de Zamora, describió así los rasgos de la cultura europea actual: "Un concepto de libertad que tiende a ser casi absoluta, privada de su relación esencial con la verdad y su arquitectura moral. Una distorsión del concepto de tolerancia que conduce al relativismo moral y al agnosticismo religioso. Una sobrevaloración de la categoría de lo útil que se antepone a lo bueno y una hipertrofia de lo placentero que se sobrepone a aquello que produce auténtica y profunda alegría. Una democracia animada por este caldo vital revela cada día su propia enfermedad" 7 .

Dentro de la cultura actual europea existen unos rasgos que repercuten directamente en la fe cristiana e indirectamente bloquean la vocación. Así expuso la situación en el Sínodo europeo de 1999 el Arzobispo de Toledo: "constatamos la preocupante descristianización de nuestro continente con la aparición de un neopaganismo materialista, la difusión de una vaga religiosidad e, incluso, de un ateísmo práctico. Esta descristianización la sentimos los obispos en nuestras carnes, por la constante separación entre progreso material y valores del espíritu, que distorsionan la visión trascendente del hombre, con la pretensión de querer reducir el influjo de los cristianos a una esfera meramente privada e individual. En esta situación resulta decisiva la alar-

${ }^{7}$ Crónica sobre el Sínodo. En Vida Nueva 2.207 (1999) 20. 
mante disminución de vocaciones al ministerio ordenado, a la vida consagrada y, también, a la militancia apostólica" 8 .

c) Los educadores de los jóvenes. En el cuadro histórico-cultural conviene constatar la situación de los educadores de los jóvenes. Hoy se habla con fundamento de crisis de vocacionados y de "vocantes" (padres de familia, educadores y militantes. Cf. PDV 7). Bastan algunos detalles que confirman la crisis como es el bajo índice natalidad en España, el más bajo de toda Europa (1,2 hijo por mujer), la creciente gravedad de los problemas familiares y pedagógicos derivados de la desestructuración familiar... viudedad, ancianidad de la pareja... marginación social... católicos unidos sólo difícilmente, pero que piden los sacramentos para sus hijos, el problema de los divorciados vueltos a casar, los malos tratos a menores... mujeres maltratadas o desasistidas económica y judicialmente...

Los educadores (dentro y fuera del hogar) no escapan a la cultura del subjetivismo que considera a la persona como criterio y medida de toda opción de vida y que exalta la inteligencia práctica por encima de los valores intelectuales y espirituales con el riesgo de un exagerado pragmatismo. Junto al porcentaje no muy elevado de educadores sensibles a la fe y cercanos a la Iglesia, está ese $12 \%$ de enseñantes en ejercicio que profesan un ateísmo militante.

\section{El joven actual: rasgos positivos y negativos}

Es difícil enumerar por separado los rasgos positivos de los negativos en el joven actual. Destacamos algunos de los más significativos. Tenemos presente el Documento final del Congreso Europeo sobre las Vocaciones al Sacerdocio, Nuevas vocaciones para una nueva Europa. De este Documento sacamos algunos de los rasgos del joven europeo y también del Instrumento de trabajo de la Comisión episcopal de seminarios y universidades sobre Pastoral vocacional de la Iglesia en España ${ }^{9}$.

8 Mons. Francisco Alvarez, En Ecclesia, 23-X-99 n. 2.968(1999) 1605-1618.

9 Congreso Europeo sobre las Vocaciones al Sacerdocio y la Vida consagrada en Europa, (Roma 5-10 de mayo de 1997): Nuevas vocaciones para una nueva Europa, 17-22. El Instrumento de trabajo de la Comisión episcopal de seminarios y universidades sobre Pastoral vocacional de la Iglesia en España, EDICE, Madrid 1988, 30-32-34. 
a) Bajo el influjo de la cultura. El joven hijo de su tiempo vive en su cultura que es pluralista y ambivalente, politeísta y neutral. Una cultura que por diversos conductos le impulsa a elegir una profesión reducida a lo económico o a la satisfacción sentimental-afectiva con la ilusión de ser libres, sin apertura al misterio y a la transcendencia. El joven anhela la independencia pero se ve simultáneamente sometido a muchos valores y ambientes socioculturales. Son muchos los jóvenes que se sienten fundamentalmente solos, heridos por el bienestar, engañados por las ideologías, confusos por la desorientación ética.

La cultura, pródiga en comunicaciones, lanza reclamos e informaciones contradictorias pero sin puntos de referencia. De aquí la dificultad en el joven para establecer relaciones verdaderas, formadoras y programáticas. Grupos de jóvenes viven como en bolsas protegidas de la droga, del sexo exacerbado en torno a los adultos de religiosidad tradicional.

b) Matices de su psicología. Junto a los rasgos propios de la edad se unen dos aspectos necesarios para comprender al joven actual europeo: la reivindicación de la subjetividad y el deseo de libertad. Aspiraciones que en muchos jóvenes terminan en subjetivismo y en arbitrariedad.

En torno a este núcleo de subjetividad-libertad se constata una identidad imperfecta y frágil, una indecisión crónica ante la opción vocacional. Su misma vida intelectual es de nómada, propia de quien va tanteando, con mucha información pero con poca formación. No puede el joven actual evitar el miedo al futuro, cierto desasosiego ante compromisos definitivos. Muchos se sienten superfluos o sobrantes en el drama de la vida; están como extraviados, sin vocación y sin futuro, hasta les falta la voluntad de vivir, de crecer en algo, de tender hacia objetivos grandes.

¿Es grave lo que sucede a la juventud actual? "La juventud no está, como a veces se piensa, tanto en crisis de valores como padeciendo una 'latencia' de valores que no ha descubierto todavía de una manera clara y estable. Busca más una imagen global que valores concretos y por eso le cuesta lo "racional"' 10. La situación es grave pero con esperanzas.

${ }^{10}$ El Instrumento de trabajo de la Comisión episcopal de seminarios y universidades sobre Pastoral vocacional de la Iglesia en España, EDICE, Madrid 1988, 30, 33 
Otros rasgos que también integran la psicología del joven actual es la debilidad en sus preguntas. Sin embargo aprovecha la ocasión para exaltar la imagen de sí mismo con el recurso del espejismo de las emociones y de las experiencias en plural. En muchos se da el negativismo propio de quien se afirma negando, más que con afirmaciones positivas. En una gran mayoría el desencanto de los grandes ideales se convierte en escepticismo.

Entre los aspectos positivos encontramos la búsqueda de la autenticidad y la simpatía por la vida como valor absoluto, sagrado y como experiencia necesitada de sentido; el compromiso en las experiencias de solidaridad, de amor a los otros; la tolerancia pero a veces es más fruto de su desvertebración que de la valoración del otro y de sus posturas...

\section{$2^{\circ}$ EL CONTEXTO DE EVANGELIZACION}

Una segunda tarea para la Pastoral vocacional con énfasis contextual es la descripción de la situación del joven ante la fe cristiana, ante la comunidad eclesial y ante la vocación. Así mismo tiene como tarea el discernir sobre el tipo de evangelización más apropiado para promover la posible vocación al sacerdocio del joven, del adolescente o del niño de nuestro tiempo.

\section{El contexto histórico-cristiano que envuelve al joven}

¿En qué contexto histórico-cristiano se encuentra el posible candidato a la vocación sacerdotal? ¿Cómo se encuentra él mismo ante la fe, la Iglesia y la práctica religiosa? Algunas respuestas encontramos en las intervenciones de varios Obispos españoles participantes en el $2^{\circ}$ Sínodo dedicado a Europa con el lema Jesucristo, viviente en su Iglesia, fuente de esperanza para Europa. (Roma, octubre de 1999). El joven, más que el adulto europeo hoy día se encuentra:

a) Deslumbrado por los nuevos dioses. Afirmó el arzobispo de Oviedo en el Sínodo: "Dios es para estos cristianos una idea, algo propio de una cultura ya superada e incompatible con el progreso de la 
sociedad. La nueva cultura adora el éxito temporal, el dinero, la libertad desligada de los valores objetivos, y se infiltra por los poros de la sociedad trasvasada incesantemente por los medios de comunicación social" 11. Podemos completar el cuadro con las palabras del arzobispo de Pamplona: “el Dios de Jesucristo comparte soberanía con otros dioses no confesados pero realmente adorados, como el dinero, la libertad omnímoda, el bienestar a corto plazo" 12 .

b) Bloqueado por el humanismo inmanentista y por la secularización. Para el obispo de Zamora, el humanismo inmanentista "es el trasfondo del panorama espiritual europeo que envuelve e impregna a casi todos nuestros conciudadanos, dificultando gravemente el despliegue y la misma emergencia de la fe. No es extraño por tanto que la fe de muchos cristianos se resiente hoy en su identidad, en su integridad, en su entusiasmo vital, en su coraje moral, en su capacidad transmisora" 13 .

La otra raíz cultural más importante que bloquea la fe cristiana es la secularización. Sus efectos son descritos con detalle por Mons. Fernando Sebastián: "la secularización cultural y espiritual ha afectado a muchos miembros de la Iglesia. Consecuencia de ello es el debilitamiento de la adhesión de fe a la revelación de Dios, el cuestionamiento teórico y práctico de la moral cristiana, el abandono masivo de la asistencia a la misa dominical, la no-aceptación del magisterio de la Iglesia en aquellos puntos que chocan con las preferencias de la cultura dominante. El secularismo cultural deteriora progresivamente la conciencia de los cristianos y este debilitamiento de la fe y de la vida de los cristianos favorece el fortalecimiento y la implantación de la cultura secularista. Es lo que podríamos llamar el círculo de la descristianización" 14 .

c) En un ambiente descristianizado y casi pagano. El arzobispo de Toledo denunció la descristianización de Europa, la aparición de un neopaganismo materialista e incluso, de un ateísmo práctico. Existe la

11 Mons. Díaz Merchán. En Ecclesia, 23-X-99 n. 2.968 (1999)1609-1610).

12 Mons Fernando Sebastián. En Ecclesia, dc.1613-1614.

13 Mons. Uriarte. En Ecclesia, dc.1617-1618.

14 Mons Fernando Sebastián. En Ecclesia dc, 1613-1614. 
pretensión de reducir el influjo cristiano a una esfera meramente privada ${ }^{15}$. No menos realista es Mons. Sebastián al afirmar categóricamente que "hoy la mayoría de los bautizados viven más o menos como los paganos, no aceptan el magisterio moral de la Iglesia, no creen ni esperan la vida eterna, no están dispuestos a renunciar a nada para vivir como verdaderos discípulos de Jesucristo" 16.

d) En una Iglesia que no es aceptada. Un fruto del ambiente secularista es "la no-aceptación del magisterio de la Iglesia en aquellos puntos que chocan con las preferencias de la cultura dominante" 17. Mons. Díaz Merchán concreta más la situación de rechazo de la Iglesia: "junto a esta actitud alejada de Dios y del Evangelio se une la agresividad persistente ante la institución eclesial y clerical: muchos cristianos recelan de la Iglesia cuando propone principios de fe o de moral" 18.

e) En comunidades eclesiales con poco influjo evangelizador. En el ambiente eclesial actual según Monseñor Sebastián, arzobispo de Pamplona, no aparece la reacción suficiente, "no estamos siendo capaces de poner en marcha una acción evangelizadora y misionera que actúe como verdadera 'fuerza de Dios'... y que sea capaz de suscitar la 'obediencia de la fe' entre nuestros hermanos y conciudadanos" (cf. Rom 1,5. 16)...'Una Iglesia tan ambigua (la que ha descrito en su dinamismo), tan carente de claridad, con tan mala conciencia no tiene fuerza interior para anunciar el Evangelio de manera convincente ni tiene tampoco la autoridad moral de un verdadero testigo" 19.

f) ¿Es una excepción el creyente cristiano de España? Dentro del cuadro cristiano, España no es una excepción. España es un pueblo que se considera en su inmensa mayoría cristiano, pero en el que sólo una minoría conoce y practica su fe cristiana católica" ${ }^{20}$. Y más adelante,

15 Mons. Francisco Alvarez. En Ecclesia, dc. 1605-1606.

16 Mons Fernando Sebastián. En Ecclesia, dc.1613-1614.

17 Mons Fernando Sebastián, dc.

18 Mons. Díaz Merchán. En Ecclesia, dc. También apunta como una de las causas del rechazo: en España la excesiva unión con el poder civil y otros poderes.

19 Mons. Fernando Sebastián, dc.

20 IV SÍNODO DE LA DIÓCESIS DE ALMERÍA, Constituciones sinodales. Almería 1999. Libro II La Iglesia de Almería convocada por la Palabra. Situación actual 197. 
al aplicar los tres posibles grupos socio-religiosos que describe el Directorio General para la Catequesis (cf. Congregación para el Clero, 1997, n.58), concluye que predomina claramente el segundo grupo, es decir, el alejado de la práctica religiosa, poco o nada formado y normalmente desafecto a la institución eclesial, "grupos de bautizados que han perdido el sentido vivo de su fe, llevando una existencia alejada de Cristo y de su Evangelio" 21. Esta situación se agrava aún más con la aceptación, por parte de una gran mayoría de cristianos, de los postulados de la cultura moderna dominante según los cuales la fe es un asunto estrictamente privado y personal que, o bien afecta a las emociones y sentimientos íntimos, pero sin tener nada que ver con los otros aspectos de la vida personal y social, o admitiendo su influencia, se considera que no debe expresarse públicamente en acciones y organizaciones identificadas como cristianas 22 .

Predomina claramente el segundo grupo; grupos de bautizados que han perdido el sentido vivo de su fe, llevando una existencia alejada de Cristo y de su Evangelio: existe una pequeña minoría no cristiana, formada principalmente de inmigrantes, y otra, mucho mayor que la anterior, de cristianos comprometidos con la fe, pero lo que realmente abunda es el alejado de la práctica religiosa, poco o nada formado y normalmente desafecto a la institución eclesial.

\section{El joven ante la fe, la Iglesia y la posible vocación}

En el entorno religioso que acosa al joven es fácil deducir su actitud como víctima y también como actor de la vida cristiana. La crisis ética influye en los valores religiosos que también por el joven son desestimados o escasamente apreciados. Él también simpatizará con las formas de religiosidad sin Dios o con gran ambigüedad religiosa y moral (Cf. PDV 6).

a) Rasgos de su espiritualidad. En los documentos citados Nuevas vocaciones para una nueva Europa y en el otro Pastoral vocacio-

En Adelante este Documento será citado con IV Sínodo de Almería. A continuación el Libro y la página correspondiente. Cuando se trate de alguna Orientación en el texto o aquí en las notas se pondrá Or. Si se trata de alguna Norma canónica, se pondrá Nor.

21 IV Sínodo de Almería, dc. 197-198

22 IV Sínodo de Almería, dc. 215 
nal de la Iglesia en España aparece también, junto al perfil externo, la interioridad espiritual del joven. Algunos rasgos quedaron anotados al describir el contexto cultural. Pero son insuficientes. Se puede añadir la disminución del sentido moral y una fragilidad en su vida de fe. Pero esto no impide que el joven presente una gran sed de trascendencia que al mismo tiempo niega o relativiza. Son muchos los que sienten nostalgia de lo profundo, deseos de comunicarse con Dios en silencio. Y, por supuesto, profesan una gran simpatía por los modelos de radicalidad, de encarnación de los valores evangélicos y de la figura de Jesús. En cuanto al futuro es visto en una óptica consecuente, limitada a las propias ideas, en función de intereses estrictamente personales (la autorrealización).

Los hechos se imponen: una inmensa mayoría de los catequizados hasta la juventud, pasan a ser como adultos, indiferentes ante el mensaje de la Palabra, víctimas del secularismo que les aparta de una fe coherente. No tienen contacto con el sacerdote. Quizás lo tuvieron de niños como monaguillos, en la primera comunión y algunos en la preparación y recepción de la confirmación, pero después en la Universidad predominó el alejamiento y los prejuicios contra la institución eclesial. Esto no quiere decir que existan grupos de jóvenes muy coherentes con la fe cristiana y muchos de ellos muy simpatizantes de la vocación al ministerio sacerdotal. Esta faceta es menos atrayente para el porcentaje tan alarmante de jóvenes que no se acercan a la Iglesia: lo de la obligatoriedad de la Misa no les va.

b) Ante la Iglesia y la práctica religiosa. El joven integra el porcentaje alarmante de católicos que viven alejados de la Iglesia a la que no conocen y con la que no se sienten vinculados, antes bien, alimentan muchos prejuicios contra ella. Una gran mayoría de jóvenes, (el porcentaje es mayor en relación con los adultos mayores de 50 años), son creyentes pero no practicantes como indica el escaso porcentaje de los que participan con asiduidad en la eucaristía dominical. Para muchos, las celebraciones sacramentales no pasan de ser actos sociales o culturales donde están ausentes la fe viva y una consciente participación. Antes quizás el joven confesaba el pecado de no asistir los domingos a la misa, después, metido en la Universidad, justifica su respuesta y actitud. Más aún, critica a la Iglesia por imponer tal impo- 
sición a su libertad. Capítulo aparte son los jóvenes que tienen ocupado el fin de semana en sus diversiones y a quienes ni les pasa por la cabeza la posibilidad de asistir a la Misa.

El joven, quizás, en la infancia fue catequizado, pero ve cuántos son los adultos indiferentes ante el mensaje de la Palabra, y, víctimas del secularismo, se apartan de una fe coherente. Cuando llega la ocasión de "casarse por la Iglesia", un porcentaje reducido es coherente y reciben el sacramento del matrimonio con preparación y con perspectivas futuras de vida cristiana conyugal. Pero muchos, si se casan por la Iglesia, es por presiones familiares o sociales. Habrá que ver si aceptan lo esencial del sacramento del matrimonio.

Si el joven es sensible a la problemática social comprueba también la indiferencia o raquitismo en la opción coherente por los pobres por parte de muchas personas cercanas a la Iglesia y a las prácticas religiosas. Comprueba asimismo que para muchos el compromiso religioso se da sin incidencia ni implicación en los problemas de fondo que afectan a los necesitados. Son actitudes paternalistas que no promocionan a los pobres sino que los mantienen en una actitud pasiva y de dependencia de sus bienhechores. Observa que es falsa la caridad de quienes de hecho manifiestan con sus obras más la vanidad social y menos la motivación evangélica que pide generosidad, humildad y silencio. El Congreso europeo sobre las vocaciones constata que "los jóvenes con frecuencia no ven en la Iglesia el objeto de su búsqueda, ni el lugar de respuesta a sus interrogantes y expectativas. Se resalta que no es Dios el problema, sino la Iglesia [...] En un amplio sector de jóvenes perdura el temor a que una experiencia en la Iglesia coarte su libertad" 23. Pocos son los buscadores de algo que creen poder encontrar en la Iglesia, incluidos los que se formaron en colegios religiosos.

c) Crisis vocacional. De los datos y reflexiones anteriores se deduce la crisis vocacional como descenso del número de jóvenes que optan por el sacerdocio. No hace muchos años se hacía eco de esta crisis la Pastores dabo vobis: "el contexto cultural al que aludimos, cuyo influjo no está ausente entre los mismos cristianos y especialmente entre los jóvenes, ayuda a comprender la difusión de la crisis de las

23 Congreso Europeo... Nuevas vocaciones... dc. Proposición n. 7 
mismas vocaciones sacerdotales, originadas y acompañadas por crisis de fe más radicales. Lo han declarado explícitamente los Padres sinodales, reconociendo que la crisis de las vocaciones al presbiterado tiene profundas raíces en el ambiente cultural y en la mentalidad y praxis de los cristianos" (PDV 37) ${ }^{24}$. En el mismo sentido se pronunciaba años después la Comisión episcopal española de seminarios y universidades "Nadie desconoce que en estos momentos Europa occidental está atravesando una seria crisis de vocaciones. Nuestra realidad no es ajena a esta situación" 25. Y la Comisión episcopal de seminarios y universidades, en Valor actual del Seminario menor: "en los últimos años los seminaristas menores han descendido notablemente en el conjunto de las Diócesis y generalmente el número en cada Seminario también es relativamente bajo" 26 . Esta crisis como descenso de vocaciones fue descrita en sus causas y frutos en el Sínodo aludido de 1999: "En esta situación resulta decisiva la alarmante disminución de vocaciones al ministerio ordenado, a la vida consagrada y, también, a la militancia apostólica" 27.

Y no solamente se trata de una crisis de numero menor en las vocaciones. Lo más grave es lo que denunció el Documento final del Congreso Europeo sobre las Vocaciones: «estamos ante una sensibilidad y mentalidad que corren el peligro de diseñar una especie de cultura antivocacional. Que es tanto como decir que, en la Europa culturalmente compleja y privada de precisos puntos de referencia, semejante a un gran panteón, el modelo antropológico prevalente fuese el del 'hombre sin vocación'» 28.

¿No existe nada esperanzador en esta crisis vocacional? Sí, la existencia de grupos de jóvenes creyentes practicantes y militantes que

24 CEE. Conferencia Episcopal Española, La formación sacerdotal. Enchiridion . (Documentos de la Iglesia sobre la formación sacerdotal) (1965-1998). Comisión Episcopal de Seminarios y Universidades, Madrid 1999. En este Enchiridion citaremos los documentos del Magisterio. Así la cita de PD 37 con la cita cf. Propositio 13 está en el número 592 del Enchiridion

25 CEE, La formación sacerdotal, Enchiridion, Documentos de la Iglesia sobre la formación sacerdotal (1965-1998). n. 3204

${ }^{26}$ CEE. La formación sacerdotal, oc. Comisión Episcopal de Seminarios y Universidades. en Valor actual del Seminario menor. (21, noviembre 1998), n.3203

${ }^{27}$ Mons. Francisco Alvarez. En Ecclesia, dc. 1605-1606.

28 Congreso Europeo... Nuevas vocaciones... dc. 19. 
"parecen más abiertos que en otros tiempos anteriores a la llamada del Señor y se sienten interesados por encontrar su compromiso dentro de la Iglesia. Esto hace alumbrar una esperanza para las vocaciones de especial consagración, si se da un trabajo pastoral adecuado" 29.

\section{La Pastoral vocacional en el contexto de la Pastoral de misión}

¿En qué contexto de evangelización habrá que insertar la Pastoral vocacional? ¿Pastoral de cristiandad o Pastoral de misión? La Pastoral vocacional contextual debe partir de la situación del cristiano y aplicar el tipo de evangelización que más convenga al joven para presentarle la oferta vocacional y para ayudarle a discernir el camino a seguir. Toda Pastoral vocacional forma parte de la gran Pastoral de la Iglesia. Lo mismo sucede con la Pastoral vocacional contextual que debe estar integrada en el 'todo' de la pastoral general. No puede caminar una pastoral particular (vocacional, juvenil, etc.) en un sentido diferente ni mucho menos en contra de los criterios de la pastoral general.

Otro criterio a tener en cuenta es el pluralismo que está presente en toda acción evangelizadora y que consiste en dar respuestas adecuadas según sea el contexto cultural y cristiano. La promoción vocacional, como toda respuesta evangelizadora, es pluralista y debe actuar según situaciones y posibilidades del joven candidato a la vocación. Para algunos ambientes o edades quizás todavía sean más oportunos los métodos de la Pastoral de cristiandad, pero quizás otros contextos culturales (la mayoría) están pidiendo la respuesta que puede dar la denominada Pastoral de misión.

a) Una Pastoral de cristiandad en declive. Hay que valorar los méritos vocacionales de una época de cristiandad con la pastoral correspondiente. Antes del Vaticano II y después, pero con menos intensidad y extensión, ha regido en la Iglesia europea una Pastoral de cristiandad con sus valores y carencias. No se puede negar que a la sombra de esta Pastoral de cristiandad existió una promoción vocacional que ha dado muchos frutos en número y en calidad de vocaciones.

${ }^{29}$ En el Instrumento de trabajo de la Comisión episcopal de seminarios y universidades sobre Pastoral vocacional de la Iglesia en España, dc. 33-34 
En España la cumbre vocacional ha estado por los años 50-60 aproximadamente. Todo el reconocimiento para la Pastoral de cristiandad que supo responder a las necesidades de la Iglesia y a la situación del creyente, cristiano más o menos. Pero hoy día el panorama es totalmente diferente tal y como ha sido descrito en las páginas anteriores y que ahora resumimos 30 :

- la sociedad vive bajo el secularismo y en un buen porcentaje hostil a la Iglesia, el cristiano en su gran mayoría está alejado de la práctica religiosa eclesial,

- muchos de los destinatarios de la pastoral eclesial o no tienen fe, o la han perdido casi del todo o no la han adquirido nunca en el ámbito personal; viven en un ambiente que se organiza y funciona al margen de la Iglesia;

- la familia ha perdido influjo en la transmisión de valores religiosos;

- la cultura ambiental ha cambiando. Con el paso del tiempo, cambió rápida y profundamente la cultura. El cristiano vive de manera muy diferente su fe y la Iglesia en el Vaticano II se pronunció con nuevos énfasis pastorales. Los diversos cambios socioculturales y políticos que han tenido lugar en estos decenios y que se han traducido en un ambiente de mayor libertad y de menor influjo de la tradición y del ambiente, han minado las bases de la pastoral de cristiandad, manifestando una serie de deficiencias que debe superar para afianzar la Iglesia sobre cimientos firmes.

Conclusión: la Pastoral de cristiandad está en declive y la promoción vocacional no se puede actuar en el contexto de la evangelización tipo-cristiandad que se desarrollaba sobre una población ambiental y culturalmente católica.

b) Opción por una Pastoral de misión. La opción como reto fue planteada en 1986 en el Congreso sobre el tema La evangelización y hombre de hoy: "el reto más importante al que se enfrentan hoy nuestras Iglesias diocesanas es el paso de una Iglesia de cristiandad a una Iglesia en estado de misión" ${ }^{31}$.

30 Los criterios están tomados del IV Sínodo de Almería, dc. Libro II La Iglesia de Almería convocada por la Palabra 202, 200. Y de la Introducción al tema 197-199.

31 CEE, Actas Congreso de Evangelización y hombre de hoy, Madrid 1986, 544. 
Hoy el reto se convierte en una opción clara y urgente como ratifica el Sínodo diocesano de Almería: "en este Sínodo, la Iglesia de Almería hace una opción seria por la pastoral de misión en los diversos campos de su actuación". Y más adelante detalla la opción pastoral: "de esta forma, de las tres fases del proceso evangelizador, evangelización primera, acción catequética y acción pastoral, la pastoral de misión da prioridad a la primera, potenciándola en sí misma, y haciendo que sus objetivos estén presentes en las otras fases del proceso, supliendo posibles carencias" 32 .

Esta opción por una pastoral de misión está respaldada por el Concilio Vaticano II que urgió la necesidad de una fe más conocida, más personalizada y más comprometida. Así mismo la evangelización tipo-misión entra mejor en los rasgos de la nueva evangelización preconizada por Juan Pablo II y que pide que la evangelización sea nueva en su ardor, en sus métodos y en su expresión ${ }^{33}$.

En coherencia con esta opción, la Pastoral vocacional ha de tener presente los acentos y exigencias de una pastoral misionera ${ }^{34}$. Así mismo tomará conciencia de quiénes son los jóvenes, destinatarios de la oferta vocacional:

- aquellos que recibieron el bautismo pero viven al margen de toda la vida cristiana, son los cristianos no practicantes que conservan un fondo religioso y de piedad particular;

- también están las gentes sencillas de la religiosidad popular pero que desconocen los fundamentos de la fe;

- y, por último, los cristianos de cierta cultura pero con formación religiosa deficiente y que necesitan un replanteo y maduración de su fe. Y los que ocultan su identidad cristiana por un ecumenismo mal entendido.

La Pastoral vocacional tomará criterios, recursos-técnicas de la Pastoral de misión para entrar en contacto con los posibles protagonis-

32 IV Sínodo de Almería, Libro II La Iglesia de Almería convocada por la Palabra, dc. 201 y 202. El capìtulo 11.1 trata del Servicio a la Palabra en un contexto de misión 199208.

33 JUAN PABLO II, Discurso a la Asamblea del Celam en Haití. En Ecclesia 2119, (1983), 15.

34 IV Sínodo de Almería, Libro II La Iglesia de Almería convocada por la Palabra, dc. 203-204 y 206. 
tas de la vocación sacerdotal. Por ejemplo tendrá presente El Directorio General para la Catequesis: para dar un carácter misionero y no estrictamente catecumenal a niños y jóvenes. Los mismos agentes de la Pastoral misionera tendrán presente el énfasis vocacional sacerdotal de la fe cristiana 35 .

\section{$3^{\circ}$ EL CONTEXTO ECLESIAL CORRESPONSABLE}

Sobre el contexto cultural-histórico está el contexto de la evangelización. Y encima de éste, situamos la corresponsabilidad del contexto eclesial. Son como tres círculos circuncéntricos que dan sentido a la Pastoral vocacional situada en el centro y beneficiada, en su dimensión contextual, de los criterios, orientaciones y normativas de otros enfoques de la pastoral. También podemos imaginar los tres contextos como los cimientos sobre los que se apoya una Pastoral vocacional que depende de la corresponsabilidad de las otras facetas de la pastoral.

¿Qué rasgos asignamos al contexto eclesial que estén en mayor consonancia con la Pastoral vocacional? Destacamos, entre otros, la corresponsabilidad eclesial, el énfasis vocacional en la evangelización, la presencia de Cristo en la Liturgia y el testimonio convincente de la caridad social. Estas facetas corresponden a los cuatro grandes temas tratados en el Sínodo diocesano de Almería 36:

\section{Corresponsabilidad eclesial}

La Pastoral vocacional integra el dinamismo de la Iglesia donde todos los miembros unidos colaboran en la promoción de las diversas

35 IV Sínodo de Almería, Libro II La Iglesia de Almería convocada por la Palabra, dc. 207 y 208.

36 IV. Sínodo de Almería. Cuatro son los temas. La corresponsabilidad eclesial, está en el primer tema: La Iglesia del Señor que está en Almería. El énfasis vocacional en la evangelización, es uno de los paradigmas del segundo tema: La Iglesia de Almería convocada por la Palabra. La presencia de Cristo en la Liturgia, enfoque del tema tercero: $L a$ Iglesia de Almería celebra los misterios de Cristo. Y el testimonio de la caridad social viene a ser el nervio del cuarto y último del Sínodo: La pastoral caritativa y social en una Iglesia evangelizadora. 
vocaciones. El contexto eclesial corresponsable de la Pastoral vocacional es la expresión de toda una Iglesia dinámica que crece en cristianos dispuestos a servir según la llamada del Señor. ¿Qué rasgos presenta esta Iglesia dinámica? ¿Cómo vive la corresponsabilidad? ¿Cuáles son las aplicaciones a la Pastoral vocacional?

a) Respuesta en el mensaje del Sínodo. El tema primero del IV Sínodo diocesano de Almería trata sobre La Iglesia del Señor que está en Almería ${ }^{37}$. El documento desarrolla ante todo las dimensiones de la Iglesia como un misterio de comunión que a su vez es de misión que fructifica gracias a la corresponsabilidad, exigencia de primer orden en todos los miembros que integran el Pueblo de Dios. En este Pueblo de Dios cada miembro es fiel a su vocación desde la corresponsabilidad. Así el sacerdote con el seguimiento radical de Cristo pastor, los fieles laicos con su misión específica en la comunidad eclesial y los consagrados con la diversidad de carismas y tareas eclesiales propios de una vida consagrada. A todos compete la realización de la Pastoral vocacional que comprende los diversos llamamientos y respuestas en el único Pueblo de Dios.

Para responder a la misión de la Iglesia están las estructuras diocesanas con sus delegaciones y secretariados que canalizarán la comunión y la corresponsabilidad en las diversas áreas eclesiales y, cómo no, en la Pastoral vocacional.

¿Qué orientaciones iluminan el camino a seguir y qué normas canónicas han sido adoptadas para que la Iglesia de Almería sea fiel al Señor en el momento presente? Entre las muchas orientaciones y normas que recoge el Documento resumido hay que destacar las que están conectadas con la corresponsabilidad y la Pastoral vocacional.

37 El Libro I del Sínodo diocesano de Almería contiene el texto del tema La Iglesia del Señor que está en Almería (99-194). El cap. 11: La Iglesia del Señor (misterio, comunión y misión, iglesia diocesana. El cap. 21 El Pueblo de Dios (vocación cristiana, vocación a la santidad, vocaciones específicas, formación). El Cap. 31. Estructuras diocesanas: comunión y corresponsabilidad (el obispo, del gobierno de la diócesis, estructura fundamental de la iglesia diocesana, estructuras de participación y corresponsabilidad). Al final: las Orientaciones pastorales y las Normas canónicas. 
b) La corresponsabilidad eclesial. La corresponsabilidad es uno de los temas que más subraya el documento sinodal ${ }^{38}$. Baste la enumeración de algunos de las manifestaciones de la corresponsabilidad:

- el conocimiento, admiración, amor y sano orgullo de pertenecer a la comunidad eclesial católica;

- el descubrimiento de la propia vocación. Tomar conciencia de ser llamados a evangelizar en, desde y con la Iglesia;

- la solidaridad eclesial, vivencia de la dimensión comunitaria de la fe y de ser miembro del Pueblo de Dios, comunión, comunidad servidora, sacerdotal y profética;

- la preocupación coherente por el bien de la comunidad eclesial con la interiorización de los nuevos derechos y deberes eclesiales;

- la colaboración coordinada en la misión de la Iglesia estando presente junto a otros miembros en obras apostólicas (LG 7; 1Cor 12, $1 \mathrm{~s})$;

- la responsabilidad individual pero de signo eclesial que se manifiesta en respuestas de fidelidad, docilidad, servicio individual y testimonio;

- el compromiso serio, ratificado o no por votos, de trabajar por la Iglesia desde el sacramento del Orden, la vida consagrada o el compromiso como laico;

- la participación litúrgica de quien se ofrece con Cristo Cabeza ejerciendo la función sacerdotal, profética y real de Cristo (LG 10,11,31);

- la comunicación de bienes siguiendo el testimonio de las primeras comunidades cristianas que compartían la fe, los bienes materiales y la vida litúrgica (cf. Hch 2,42-47) (LG 4, 12,13).

c) El contexto vocacional en la corresponsabilidad eclesial. En una Iglesia dinámica por su comunión y misión corresponsable tiene lugar la Pastoral vocacional. Hoy día es muy difícil que surjan voca-

38 Cap. La corresponsabilidad como tal en .62; todos activos, 66. De la igualdad en al Pueblo de Dios a la corresponsabilidad de todos 76. Corresponsabilidad en el sacerdote 84, en los laicos. 92: Llamados a corresponsabilizarse edificando la comunidad eclesial 97, en ministerios laicales, consejos 97 . El ejercicio de la corresponsabilidad 117. Estructuras de participación y corresponsabilidad en la Igl. Diocesana 132, delegaciones y secretariados 140s. La corresponsabilidad está presenta en las Orientaciones nn. 6, 5, 16, 17, 25, 27. 
ciones si no existe el esfuerzo corresponsable de los miembros de la comunidad eclesial. Presuponemos los criterios generales de Pastoral vocacional para fijarnos en lo que pide el sentido contextual y corresponsable de una Pastoral vocacional ${ }^{39}$ :

$1^{\circ}$ tomar conciencia de la dimensión eclesial de toda vocación.. Cada uno es llamado por Dios en la Iglesia y su respuesta se da desde la misma Iglesia según el tipo de vocación.

$2^{\circ}$ asumir la responsabilidad de promover todo tipo de vocación para fortalecer la Iglesia y difundir el Reino de Dios. Cada miembro corresponsable debe preguntarse qué puede o qué debe hacer por la promoción de las vocaciones: todo fiel cristiano, los padres, educadores, familiares cercanos: desear, motivar, hablar a los niños y jóvenes sobre la vocación y posibilidad de responder a Dios si les llama...

$3^{\circ}$ ayudar personalmente a los vocacionados en los diversos tipos de consagración;

$4^{\circ}$ colaborar en las estructuras diocesanas y de manera especial en las obras vocacionales con actitud "católica", universal en cuanto a carismas y naciones

$5^{\circ}$ la oración de toda la Iglesia para que el Señor envíe toda clase de vocación a su Iglesia es una petición expresa de Cristo y una exigencia primordial de la Pastoral vocacional corresponsable en el contexto del dinamismo espiritual de toda la Iglesia.

d) Función del sacerdote y de la parroquia. Dentro de la Iglesia, el sacerdote diocesano tiene una especial responsabilidad para promover las vocaciones para el ministerio presbiteral. Hay que reconocer que la propuesta vocacional por parte de muchos sacerdotes es tímida, poco interpeladora, quizás por respeto a la libertad o por desánimo personal. Así mismo las secularizaciones que conmocionaron a la comunidad cristiana son para muchos una dificultad al pensar también en un posible fracaso de su vida cristiana. El sacerdote en su contacto con niños jóvenes está llamado a suscitar todo tipo de vocación y a ofrecerse como acompañante de las mismas ${ }^{40}$.

39 El Sínodo presenta los principales criterios de la Pastoral vocacional en 108-109. $\mathrm{Y}$ en las Orientaciones nn. 34, 91-100, 103.

40 Merece destacarse la Orientación 99 donde exhorta tanto a la promoción vocacional. También se habla del tema en la or. 97 y 98. 


\section{2. Énfasis vocacional en la evangelización}

Uno de los aspectos básicos de la Buena nueva radica en la respuesta de cada uno a la llamada del Señor. Este énfasis vocacional, de una o de otra manera, se hace presente en la tarea evangelizadora. En el "todo" de la Pastoral (de misión o de cristiandad) son básicos los criterios que integran el énfasis vocacional cristiano.

a) El mensaje "vocacional" en un documento sobre Evangelización. Desde la perspectiva de la llamada de Dios y la respuesta del hombre (vocación) resumimos algunos aspectos principales del documento La Iglesia de Almería convocada por la Palabra ${ }^{41}$.

$1^{\circ}$ Situación o punto de partida. La Introducción describe la respuesta de una mayoría de bautizados: alejamiento de una fe coherente: "el resultado es un pueblo almeriense que se considera en su inmensa mayoría cristiano, pero en el que sólo una minoría conoce y practica su fe cristiana católica" 42.

$2^{\circ}$ La respuesta pastoral más adecuada. Con la base en la realidad pastoral el Documento plantea la opción de la Diócesis por una pastoral de misión tan diferente a la de cristiandad que dio respuestas grandes en lo vocacional, pero que hoy en muchos aspectos está superada.

$3^{\circ}$ Elementos de la Pastoral de misión. Esta Pastoral de misión tiene un elemento distintivo en la crisis grave de fe existente en la mayoría de los bautizados, y sintoniza con la nueva evangelización anunciada por Juan Pablo II. Los acentos y exigencias pastorales se polarizan en el mensaje bíblico donde está la llamada por parte del Señor y en la respuesta que pide fidelidad, ardor misionero, fe, sentido comunitario, testimonio personal, etc.

${ }^{41}$ En el Libro II del Sínodo está el documento La Iglesia de Almería convocada por la Palabra de Dios (195-312). Es interesante la Introducción por las observaciones de la situación religiosa de la Diócesis. Dada la importancia del documento merece transcribir la temática principal. Así el cap. 11. Dimensiones fundamentales de la nueva evangelización (en un contexto de misión y de la cultura actual). El cap. 21 Tareas de la Iglesia diocesana al servicio de la Palabra (misión "ad gentes", catequesis, enseñanza religiosa escolar. El cap. 31 Algunos ámbitos de especial relación entre fe y cultura (universidad, medios de comunicación social). El cap. 41. El servicio de la Palabra en determinados ambientes (familia, mundo del trabajo, turismo, sectas y religiosidad alternativa). Las orientaciones pastorales en 271s y las normas canónicas en 297s.

42 IV. Sínodo de Almería, dc. En la Introducción: situación actual 197. 
$4^{\circ}$ Dinamismo pastoral. Con estos fundamentos el Documento describe las acciones fundamentales y las respuestas de los agentes o vocacionados para la misión en sus diversas áreas. Una de ellas es la cultura con sus desajustes y deterioro en su relación con la fe.

$5^{\circ} \mathrm{La}$ Catequesis y lo vocacional. De las tareas que detalla el capítulo $2^{\circ}$ subrayamos las que tienen más conexión con la vocación. Al hablar de la Catequesis el Documento le asigna como objetivo: que un niño, joven o adulto llegue a ser un cristiano convencido y comprometido con su fe. Para conseguir esto es necesario iniciar en la totalidad de lo que significa ser discípulo de Cristo y miembro de la Iglesia. Desde este objetivo habrá que ofrecer una síntesis orgánica y sistemática del mensaje cristiano, ayudar a descubrir cómo se vive en cristiano, iniciar en el compromiso apostólico y misionero... educar para cambiar el mundo en que vivimos, etc.

$6^{\circ}$ Corresponsabilidad vocacional evangelizadora. Para la Catequesis se requiere la toma de conciencia de la vocación de catequista por parte de todos y que puede realizarse, entre otros modos, en la enseñanza religiosa escolar. ¡Qué gran vocación tienen los profesores católicos que imparten enseñanza en cualquier materia y está en comunicación con los padres! Ellos son los agentes primeros de evangelización de los alumnos. Los laicos católicos dedicados a la enseñanza deben descubrir su vocación como testigos del Pueblo de Dios, que realizan con su trabajo una tarea trascendente para la Iglesia.

$7^{\circ}$ Ámbitos para la evangelización. Con esta doble base el Documento analiza, la problemática en algunos ámbitos como es la relación entre fe y cultura, las posibilidades evangelizadoras en la Universidad, los Medios de comunicación, la familia con luces y sombras que deberá afrontar una adecuada pastoral familiar. Y, junto a la familia, los otros ambientes que esperan son el mundo del trabajo que tanta problemática presenta hoy día con la inmigración, el turismo, etc. También es un reto para la evangelización eclesial las sectas y la religiosidad alternativa que necesitan una pastoral preventiva y curativa.

$8^{\circ}$ Orientaciones y normas. La inmensa problemática planteada necesita, además de los criterios y análisis expuestos, orientaciones y normativas canónicas más precisas y comprometedoras para realizar la tarea evangelizadora. 
b) Énfasis vocacional en el contexto de la evangelización. Dentro del todo de la evangelización (el contexto), el Sínodo tiene presente también la vocación en general y la promoción para las diversas vocaciones.

$1^{\circ}$ Todos comprometidos, bajo la guía de la Palabra, en la obra de Evangelización. La Pastoral es simultáneamente misionera y vocacional con el objetivo de "suscitar comunidades vivas que proclamen su fe en Jesucristo y que tengan como fin la extensión del reino de Dios". Y en esta tarea de misión todos tienen su misión, pues se pide que "los laicos asuman sus responsabilidades propias en la Iglesia diocesana, según la vocación a que han sido llamados para la evangelización del mundo". La guía vocacional es la Biblia... El Sínodo recomienda encarecidamente "la lectura sapiencial de la Biblia en las familias, grupos cristianos y parroquias, facilitando la debida iniciación" 43.

$2^{\circ}$ Todos comprometidos en la Pastoral vocacional. Dentro de la evangelización existe una tarea a tener muy presente no solamente por los sacerdotes sino también por los catequistas, los profesores de Religión y por los padres de los alumnos. ¿Cuál es?

- los catequistas "deberán promover entre los niños y los jóvenes la vocación al sacerdocio y a la vida consagrada, iniciándoles en la oración y la vida cristiana; igualmente, deberán ayudar a los padres para que comprendan la vocación de sus hijos" (236).

- por su parte los profesores de Religión "deben promover entre sus alumnos el discernimiento de su vocación cristiana. En este contexto prestarán una atención especial a la promoción de las vocaciones al sacerdocio y a la vida consagrada y ayudarán a los padres para que comprendan la vocación de sus hijos"(254).

- los padres deben ser los primeros educadores cristianos de sus hijos y acompañándoles en el descubrimiento y seguimiento de su vocación lo que conlleva su propia formación religiosa y moral ${ }^{44}$.

43 IV. Sínodo de Almería, dc. 271-291 Las citas en 273 y en 220. Los números entre paréntesis aluden a la página correspondiente del documento IV Sínodo de Almería, dc.

44 IV. Sínodo de Almería, dc. Los textos citados están sucesivamente en las páginas 236,254 y 281. 


\section{La presencia de Cristo en la Liturgia}

Cristo es el centro de toda vocación y seguir a Cristo suele ser una de las principales motivaciones del que opta por el sacerdocio. No se entiende una Pastoral vocacional si no es en el gran contexto teológico centrado en la figura de Cristo. Por ello la figura de Cristo ocupa un puesto prioritario en la Pastoral vocacional que toma los criterios de todo el mensaje cristiano: exégesis del NT (principalmente), cristología, liturgia, sacramentos, eclesiología, etc. En la dimensión contextual, la Pastoral vocacional está situada dentro de estas disciplinas teológicas.

Veamos como exponente la presencia de Cristo en algunos de los textos del documento y de las orientaciones del tema tercero: La Iglesia de Almería celebra los misterios de Cristo ${ }^{45}$.

a) La presencia de Cristo. En el documento sinodal sobre Liturgia y Sacramentos encontramos múltiples criterios que sirven como marco doctrinal para la Pastoral vocacional contextual. Elegimos algunos más significativos:

$1^{\circ}$ Cristo actuando hoy día. El capítulo primero al describir la naturaleza de la Liturgia dedica un artículo a Cristo, centro de la acción litúrgica, mediador de la salvación. "En nuestro hoy, el mismo Cristo, ya resucitado, vivo y vivificador, sigue actuando por nosotros, se acerca, se nos hace presente de diferentes maneras, y de modo especial en los sacramentos, en los que se actualiza su Pascua a lo largo del tiempo" (323)

$2^{\circ}$ Presente en la liturgia y en la Palabra. Y en el capítulo segundo que trata sobre quién celebra la Liturgia, hace referencia expresa a La Liturgia es esencialmente presencia de Cristo. "La presencia actual de Cristo en la Iglesia nos viene dada particularmente por la liturgia,

45 El Libro III del Sínodo contiene el documento La Iglesia de Almería celebra los misterios de Cristo (313-422). La Introducción alude a la situación de la temática y desafíos pastorales. Cap. 11 Naturaleza de la Liturgia (desde la historia de la salvación, como obra de la Santísima Trinidad). Cap. 21. La celebración de la Liturgia (quién celebra, cómo celebra la Iglesia, cuándo celebra, dónde celebrar, la piedad popular). Cap. 31. La celebración de los sacramentos (en general, cada uno de ellos, los sacramentales). Cap. 41. Agentes de la Pastoral litúrgica (la delegación, la parroquia, el equipo). Orientaciones 375s y Normas canónicas 401s. - NOTA: dada la abundancia de citas, y para simplificar, pondremos entre paréntesis la página del IV. Sínodo de Almería, que corresponderá al documento que se analiza. 
en la que Cristo está continuamente activo, asociándose así su Iglesia para gloria de Dios y salvación de la humanidad" (326). También trata de Cómo celebra la Iglesia el misterio de Cristo. "Dios habla a su pueblo. Cristo sigue anunciando el evangelio, y el pueblo responde a Dios con el canto y la oración" (SC 33). Aunque toda la Biblia hable de Cristo, son los Evangelios los que contienen la narración de los "hechos y palabras" realizadas por Él (332).

$3^{\circ}$ Presencia de Cristo en la Iglesia mediante los sacramentos. Todo el capítulo tercero está dedicado a la celebración de los sacramentos. Sabemos por la fe de la Iglesia que Cristo vive y actúa en ella y con ella, hasta su vuelta gloriosa, los frutos de la Redención. Y lo hace de una manera más plena y eminente en los siete sacramentos... instituidos por el mismo Jesucristo como lo explica la Iglesia. Palabra, Sacramento y Vida constituyen el medio completo por el que Cristo nos da la salvación (cf CEC 1070). Es en los sacramentos, y sobre todo en la Eucaristía, donde Jesucristo actúa en plenitud para la transformación de los hombres (cf. CEC 1074).

$4^{\circ}$ Singular presencia en el sacramento de la Eucaristía. En la Eucaristía está contenido todo el bien espiritual de la Iglesia que es Cristo mismo nuestra Pascua (cf. LG 11; PO 5). Por las palabras de Cristo y el poder del Espíritu Santo, el pan y el vino presentados se convierten en el Cuerpo y la Sangre del Señor y así Cristo se hace real y misteriosamente presente (cf CEC 1357), según la fe de la Iglesia. Cristo Jesús está presente de múltiples maneras en su Iglesia (cf. LG 48), pero sobre todo bajo las especies eucarísticas (cf SC 7). El modo de presencia de Cristo bajo las especies eucarísticas es singular, y por eso se eleva la Eucaristía por encima de todos los sacramentos. En la eucaristía está verdadera, real y substancialmente el cuerpo y la sangre de Cristo glorioso, con su alma y divinidad, es decir, Cristo entero de modo misterioso (355)

$5^{\circ} \mathrm{El}$ bautizado transformado por Cristo y comprometido ante Cristo. Incorporados así a Cristo por el bautismo, nos identificamos con Él en su muerte y resurrección, recibiendo su Santo Espíritu, que nos eleva al orden sobrenatural. Al infundirnos su gracia santificante, nos hace hijos de Dios por adopción, nos limpia de toda mancha de pecado y somos constituidos templos de la Trinidad (349). Los que se incorporan a Cristo por el bautismo quedan configurados con Él (cf 
Rm 8, 29) (351) y participan del sacerdocio de Cristo con su misión profética y real (cf $1 \mathrm{Pe} 2,9$ ). El sello bautismal capacita al bautizado para participar en la liturgia de la Iglesia y compromete a vivir en santidad de vida, ejerciendo la caridad fraterna (cf LG 10; CEC 1273) (352). Por la confirmación los bautizados "quedan obligados más estrechamente a difundir y defender la fe, como verdaderos testigos de Cristo, por la palabra juntamente con las obras" (LG 11) (352).

$6^{\circ}$ En el Domingo y a lo largo del año, todos junto a Cristo. ¿Cuándo celebra la Iglesia el misterio de Cristo? En el Domingo, día del Señor (337), y a lo largo del año litúrgico. El domingo es el día memorial de la Pascua del Señor. En este día la Iglesia se reúne en asamblea para celebrar a Cristo, su Cabeza, resucitado y presente entre los suyos". A lo largo del año litúrgico celebramos el misterio de Cristo (339), en concreto, los misterios de la redención, fuente de gracia para los fieles (339).

$7^{\circ}$ Oremos con Cristo. En la liturgia de las Horas, la oración es al Padre, por Jesucristo, en el Espíritu Santo (342). Si toda Liturgia es obra de Cristo que asocia a la Iglesia en el culto al Padre, la Liturgia de las Horas pone de manifiesto aún más esta vinculación y pone en práctica la norma dada por Jesús: "cuando oréis, decid: Padre nuestro" (Lc 11, 2)

b) Orientaciones para la presencia de Cristo en la Liturgia. La vocación de muchos jóvenes surgió como fruto de unas celebraciones litúrgicas que les entusiasmaron e hicieron brotar el deseo de poder un día representar a Cristo en el altar celebrando la Palabra y el Sacrificio eucarístico. Pero también es verdad que muchos jóvenes con incipiente vocación sacerdotal desechan la idea porque no les convence la función cultual del sacerdote y las celebraciones litúrgicas tan rutinarias y sin vida.

¿Qué hacer para que el joven se sienta atraído por Cristo en el marco de la celebración litúrgica? ¿De qué manera el contexto litúrgico-cultual-sacramental ayudará a la vocación de los jóvenes?

$1^{\circ}$ Tomar conciencia de las deficiencias litúrgicas para poder superarlas. Una deficiencia es la falta sentido de comunidad y de asamblea litúrgica. Muchos solicitan los sacramentos motivados por una fe ambigua movida, por la rutina o por una vaga religiosidad 
social, pero sin fe ni compromiso cristiano. Está también como deficiencia la utilización social de la Misa para muchas circunstancias y personas que carecen de profundo convencimiento religioso, buscando sólo la fiesta o lo estético. Piden, sí, celebraciones litúrgicas pero sin aceptar la formación catequética ni el compromiso evangélico. Es frecuente que matrimonios en situación irregular y al margen de la vida de la Iglesia soliciten los sacramentos llamados sociales (bautismo, primera comunión) sin garantías ni criterios de fe. En general, se constata una falta de formación religiosa y una deficiencia grande en el cumplimiento de los criterios litúrgicos y pastorales para administrar y recibir los sacramentos 46 .

$2^{\circ}$ Suscitar interés y proporcionar información. Para conseguir una celebración gozosa, atrayente y participada, es necesario esforzarse para que todos, jóvenes y adultos, se sientan interesados, procurando que intervengan en aquellas formas de participación que la liturgia sugiere y recomienda (Or. 346). Ante la realidad de los fieles que dicen ser creyentes pero no practicantes, el Sínodo les exhorta a que comprendan el significado del precepto dominical a la luz de una fe coherente y de las exigencias de los Mandamientos de Dios y de la Iglesia. (Or 343)

$3^{\circ}$ Educar para una vivencia cristiana de las celebraciones litúrgicas. Se requiere que la participación litúrgica asocie efectivamente a los fieles a la acción salvadora de Cristo mediante la escucha de la Palabra, la oración, la comunión, el canto, la acción de gracias, acompañados de la actitud interior (Or 323). Hay que conseguir que cada celebración alcance su expresividad poniendo los medios adecuados: formación litúrgica, catequesis, cantos y moniciones (Or 318 a 321).

$4^{\circ}$ El trato y la homilía del sacerdote. Para toda celebración el trato por parte del sacerdote sea delicado con los que se acercan a la Iglesia para solicitar algún sacramento (Or 368). Además de la dignidad y devoción con que celebra cada sacramento, está la tarea propia del sacerdote en la homilía. Se pide que el lenguaje de la homilía sea claro, sencillo, rico y concreto, al alcance de la gente sencilla, sin demasiados tecnicismos y con la debida dignidad. La homilía requie-

\footnotetext{
46 El documento sinodal tercero, La Iglesia de Almería celebra los misterios de Cristo, constata estas deficiencias en la Introducción: 314-315.
} 
re, además, un todo directo, familiar, persuasivo y ágil, que mantenga el interés de los oyentes y los interpele (325).

$5^{\circ}$ Finalidad cristocéntrica y vocacional. Toda pastoral sacramental tiene como meta fomentar la vocación cristiana de los fieles. En concreto, la Pastoral de la confirmación "tendrá como objetivo presentarles (a los candidatos) la vida cristiana como modelo a seguir, y conducirlos a una unión más íntima con Cristo y a una familiaridad más viva con el Espíritu Santo, para que así puedan asumir la responsabilidad apostólica de su vocación"... "Esta pastoral ha de proponerse que los bautizados y confirmados lleguen a ser verdaderos apóstoles y testigos de Cristo con la fuerza del Espíritu Santo, y les ayude a descubrir su vocación en la Iglesia" 47.

\section{El testimonio de la caridad social}

Servir a los hermanos es una motivación primordial en la vocación sacerdotal juntamente con el deseo de seguir a Cristo en toda la vida. Muchos jóvenes se acercan al sacerdocio por el amor a los pobres, así como otros rechazan la vocación y critican a la Iglesia por la incoherencia que ellos ven en el testimonio de la caridad social. Las motivaciones de servicio y amor son, en definitiva, la expresión de la única caridad dirigida a Dios y al prójimo: amar como Cristo el Buen Pastor.

Ha sido y será prioritario el testimonio de la caridad social en la vocación sacerdotal. Por ello, dada la importancia de la caridad en la espiritualidad sacerdotal, (la caridad pastoral es el corazón del sacerdote buen pastor), y la especial sensibilidad que hoy existe hacia lo comunitario, la Pastoral vocacional ha de tener muy presente las exigencias de la caridad fraterna. Con más claridad: la Pastoral vocacional también se mueve en el contexto (dentro de) de los criterios y técnicas de la Pastoral socio-caritativa. Esta es, precisamente, la temática del documento cuarto del Sínodo de Almería La pastoral caritativa y social en una Iglesia evangelizadora ${ }^{48}$. De este documento tomamos

${ }^{47}$ La Iglesia de Almería celebra los misterios de Cristo, dc. Orientaciones 378 y 380.

${ }^{48}$ El Libro IV del Sínodo diocesano de Almería contiene el documento sobre La pastoral caritativa y social en una Iglesia evangelizadora (423-550). El cap. 11 Los pobres en 
algunos criterios sobre el amor cristiano y algunas orientaciones para que sea convincente el testimonio de la caridad.

a) Mensaje sobre la caridad social, distintivo del sacerdote como Pastor. ¿Qué criterios ayudarán a la Pastoral vocacional a la hora de presentar la caridad pastoral? Del Documento cuarto seleccionamos algunos criterios que convertimos en objetivos.

$1^{\circ}$ Saber quiénes son los preferidos del Dios amor. Dios es amor y fuente de toda donación. Amor manifestado especialmente con el envío de su Hijo (1 Jn 4,9 3,16). Cristo, el Dios-amor entre los hombres, sitúa la caridad en el centro de la Revelación y el amor de Dios como modelo para que todos nos amemos (1Jn 3,16). Y es Cristo quien hace del pobre destinatario principal del Reino de Dios que es Reino de amor (Lc 4,18-19.21; 7, 22). Y es Pablo quien describe el proceso de Cristo: "Él, siendo rico, se hizo pobre por vosotros, para enriqueceros con su pobreza" (2 Cor 8,9$)$. No hay duda: la esencia del cristianismo está en el amor (426 y 427)

$2^{\circ}$ Interiorizar la opción preferencial de la Iglesia, comunidad de amor. Jesús ha hecho partícipes de su misión a los discípulos y ha constituido a su Iglesia como sacramento, presencia visible de su persona, de su doctrina y de su obra (429). Con toda propiedad, la Iglesia es comunidad de amor, conjunto de fieles que creen en Cristo y va poniendo en práctica el amor del Maestro. Por ello, no puede concebirse la Iglesia sin la práctica efectiva de la caridad fraterna. Más aún, su capacidad evangelizadora depende del testimonio de su amor (431). Efectivamente, "la caridad es la Iglesia viviendo en la práctica su dimensión de servicio y diaconía". La Iglesia servidora está llamada "a expresar de forma más concreta y profunda el rostro de la misericordia de Dios con los pobres mediante su cercanía y su empobrecimiento" 49 .

la identidad y misión de la Iglesia (que es una comunidad evangelizada y evangelizadora, pobre y con amor preferencial por los pobres). El cap. $21 \mathrm{El}$ amor preferencial por los pobres (la escucha de su clamor, el compromiso, promoción y comunión con los pobres). El cap. 31 Los agentes de la acción caritativa (rasgos, formación, los presbíteros, los fieles cristianos laicos y los consagrados). Cap. 41 La organización de la Pastoral caritativa y social en la Diócesis (delegación diocesana de pastoral social, cáritas, la parroquia, las instituciones de pastoral caritativa y social, los religiosos, institutos seculares y sociedades de vida apostólica, entidades de inspiración cristiana. Orientaciones pastorales 503s y Normas canónicas 525s.

49 La pastoral caritativa y social en una Iglesia evangelizadora, dc. Las citas están en las páginas 437 y 436 respectivamente. 
¿Y a quién amar con preferencia? Como Cristo, a los más necesitados, a los pobres. ¡Es una condición del seguidor de Cristo! Y un factor determinante para la Iglesia samaritana, llamada a servir a todos los pobres con el propio empobrecimiento (1Pe 25-28) ${ }^{50}$.

$3^{\circ}$ Concretar el compromiso con los pobres. El compromiso individual y comunitario con los pobres es ante todo un compromiso humano fundamentado en la justicia social, pero potenciado en el cristiano por la caridad y por la opción de seguir a Cristo (444). Quien participa en la misa dominical tiene una razón más puesto que la Eucaristía "entraña un compromiso en favor de los pobres: para recibir en la verdad el Cuerpo y la Sangre de Cristo entregado por nosotros, debemos reconocer a Cristo en los pobres, sus hermanos" (cf. Mt 25,40) (CEC 1397).

El compromiso con los pobres conlleva la práctica de las exigencias bíblicas de la justicia y del amor, según la Palabra de Dios, la enseñanza de los Santos Padres, la interpretación de la Doctrina social de la Iglesia y otras voces del Pueblo de Dios, especialmente la de los que luchan por la liberación de los empobrecidos. Lo que está claro es que hay que ser consciente del clamor de los pobres que nos interpelan. Y junto a esta toma de conciencia está la sinceridad de quien analiza lo que puede y debe realizar individualmente y en unión con otros miembros o instituciones de la Iglesia (corresponsabilidad). El compromiso implica la comunicación cristiana de bienes, el trabajar en la promoción de los empobrecidos para que ellos sean protagonistas de su liberación. Así mismo un compromiso radical por los empobrecidos invita a luchar para que desaparezcan las causas de la pobreza entre las que destaca la desigualdad afrentosa. Y habrá que tener presente que el testimonio de caridad social es incompleto sin la austeridad de vida o, lo que es más convincente, sin una vida pobre como la de Cristo, una vida en comunicación y solidaridad con los pobres.

b) El camino para el testimonio de la caridad social. ¿Son suficientes los criterios expuestos para testimoniar la caridad social? Son imprescindibles pero incompletos. Entonces, ¿de qué manera práctica

50 La pastoral caritativa y social en una Iglesia evangelizadora, dc. Citas en las páginas 431, 432, 434-436. 
debemos dar un testimonio efectivo de las exigencias de la caridad socio-caritativa? Del mismo Documento cuarto del Sínodo seleccionamos algunas orientaciones y normativas:

$1^{\circ}$ Conocer la realidad para interiorizar los valores sociales cristianos. El conocimiento de la realidad de nuestra pobreza es condición para que sea efectivo el amor preferencial de la Iglesia por los empobrecidos 51 . Junto a la necesidad de conocer la realidad está la tarea ineludible de padres y educadores cristianos de formar desde la infancia a los niños y jóvenes en los valores evangélicos y sociales: caridad, fraternidad, solidaridad, igualdad, justicia, derechos humanos, austeridad frente al consumismo, de tal forma que sean fermento para todas las familias y escuelas (Or 433 y 418).

$\mathrm{Y}$ todo cristiano tiene una doble tarea: en plan negativo está el evitar como incompatibles con el Evangelio la radicalización del espiritualismo y del secularismo al rehuir la oración o el compromiso. En plan positivo "cada miembro de la comunidad ha de tomar conciencia del significado de la pobreza evangélica, de que los bienes que no les son necesarios, no les pertenecen, según la doctrina de la Iglesia y de los Santos Padres. Por otro lado, hasta de los bienes que les son necesarios, han de hacer partícipes a los más necesitados" (Or 502).

$2^{\circ}$ Actitudes y respuestas incompatibles. Se ha de rechazar toda forma de violencia: la de la pobreza y del hambre, la de los malos tratos, etc. (Or 428). Así mismo habrá que superar el afán de ganancia excesiva a través de la acumulación de empleos y las horas extraordinarias (Or 448). Los pobres y la austeridad exigen que haya derroches en las celebraciones litúrgicas y en las expresiones de piedad popular (Or 498). De manera más concreta el Sínodo exhorta "a todos los grupos, comunidades y asociaciones cristianas, incluidas las Cofradías y Hermandades, a atender a las necesidades de un culto digno, evitando todo lo superfluo y a tener un talante de austeridad para una mayor caridad con los pobres" (Or 503).

$3^{\circ}$ Exigencias elementales pero menos fuertes. El cristiano más que nadie está urgido a cumplir los deberes sociales como es la res-

51 La pastoral caritativa y social en una Iglesia evangelizadora. Mucho iluminan el camino a seguir el conjunto de Orientaciones pastorales que ofrece el Documento. Para las exigencias anteriormente expuestas, véanse las orientaciones 419, 420 y 424. 
ponsabilidad en las obligaciones de carácter fiscal; la disponibilidad de los recursos para crear puestos de trabajo; y la honradez en el cobro del seguro de desempleo (Or 456).

Pero no basta con predicar sobre la caridad. También la caridad cristiana urge a mantener y aumentar la presencia física junto a los pobres... en los barrios pobres y en los sectores más empobrecidos, como un signo del compromiso evangélico con ellos (Or 463). Y junto a la presencia la donación: los cristianos "hemos de estar abiertos a que nuestros bienes estén al servicio de los más necesitados" (Or 506). Y en el ámbito de Iglesia diocesana, ¿a qué urge la caridad? A que sea pobre y tenga una organización sencilla y sobria, fácilmente accesible a los pobres; su estilo de vida pobre evitará el derroche y la ostentación; y orientará su dedicación y planificación principalmente al servicio de los pobres (Or 505).

$4^{\circ}$ El testimonio más convincente de caridad social. Muchos quizás respiren y crean que ya está todo dicho. Pero el Sínodo, siguiendo el espíritu de los Santos Padres y la línea del Vaticano II, (por ejemplo en GS 69), concreta otras exigencias que detallamos:

- dar hasta los bienes necesarios. "todos tienen derecho a disponer de una parte de bienes suficientes para sí y para la propia familia. Esto exige que al considerar la cosas que legítimamente poseemos como propias, tengamos presente que una parte pertenece a los hermanos que carecen de lo necesario. De aquí se desprende la obligación de compartir con los pobres y no sólo con los bienes superfluos" (Or 501). Esta orientación, al parecer utópica, es la traducción casi literal de lo que el Vaticano II recomienda en la CP. n.69.

- comunicar los bienes de todo tipo: "los cristianos individualmente, las familias y los grupos, deben seguir comunicando todo tipo de bienes, culturales, humanos y espirituales, en la medida de su crecimiento en la caridad" (Or 496).

- dedicar un porcentaje de los presupuestos: "todos los cristianos, las familias, las comunidades o grupos de la Iglesia, destinarán al menos el $1 \%$ de los fondos que gestionan para cooperación con instituciones socio-caritativas de los países del Tercer Mundo" (Or 499 y cf. 500).

- poner en práctica las normas canónicas respecto a la caridad social. Seleccionamos las que están relacionadas con las orientaciones anteriores. 
- "toda comunidad o institución eclesial destinará al menos el 1\% de los fondos que gestiona para compartir con instituciones socio-caritativas de los países del Tercer Mundo" (Norma canónica 177).

- "los presbíteros aportarán al fondo común diocesano, una parte de sus propios ingresos, según lo establecido en la diócesis, para contribuir a que todos los sacerdotes puedan tener un mínimo decoroso para su sustento" (Norma canónica 186).

\section{CONCLUSIONES}

Del tema expuesto sobre Pastoral vocacional contextual y corresponsable cabe destacar, como conclusiones más significativas, las siguientes:

$1^{a}$ Algunos criterios de la denominada Teología contextual iluminan la promoción de las vocaciones que puede adoptar el título de Pastoral vocacional contextual y corresponsable cuando se integra dentro de (en el contexto) de disciplinas sociológicas, teológicas y pastorales.

$2^{a}$ La cultura, que tanto condiciona la Pastoral general, presenta hoy día en Europa unos rasgos ético-religiosos que obstaculizan la Pastoral vocacional.

$3^{a}$. El joven actual, marcado por una cultura que ha sido calificada de antivocacional, se encuentra dominando por el secularismo, la exaltación de la libre conciencia y la visión materialista de la vida.

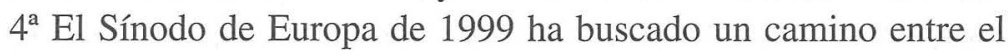
pesimismo del análisis de la realidad y el optimismo ingenuo idealista. En esa vía intermedia están las declaraciones de varios obispos españoles que han descrito el contexto histórico-cristiano con muchas dificultades para la fe y que se convierte en otros tantos obstáculos para la opción vocacional. La crisis vocacional es una manifestación pero la Iglesia sigue con oración, promoción vocacional y esperanza en un futuro mejor.

$5^{\text {a }} \mathrm{El}$ joven, especialmente después de la confirmación, se aparta en un porcentaje alarmante de la práctica religiosa y de la identificación como católico. Sin embargo en grupos cercanos a la Iglesia surge la vocación con más facilidad que en épocas anteriores.

$6^{\mathrm{a}}$ A la situación cristiana presente, hay que responder con una Pastoral vocacional adecuada que se mueva dentro de los paradigmas 
de la denominada Pastoral de misión. Sin embargo rige el pluralismo en la promoción vocacional que pide aplicar la pastoral que mejor responda a las exigencias del ambiente socio cultural cristiano.

$7^{a}$ Entre las respuestas vocacionales de la España de los noventa está la de la Diócesis de Almería. El IV Sínodo diocesano (1999) ofrece no solamente una síntesis de Pastoral vocacional actualizada, sino también expone a lo largo de sus cuatro documentos una serie de criterios que pueden integrarse en la Pastoral vocacional contextual. Entre los criterios sobresale la corresponsabilidad eclesial, el énfasis vocacional en la evangelización, la presencia de Cristo en la Liturgia y el testimonio convincente de la caridad social.

$8^{\mathrm{a}}$ La Pastoral vocacional contextual se convierte en corresponsable cuando los miembros de la comunidad eclesial colaboran unidos, desde sus carismas y posibilidades, en la promoción y acompañamiento de quienes deciden seguir a Cristo, bien como laicos comprometidos, bien como sacerdotes diocesanos o bien como miembros en la vida consagrada.

$9^{\text {a }} \mathrm{La}$ corresponsabilidad eclesial pide a todos tomar conciencia de ser miembros de la Iglesia, amarla, colaborar en las estructuras diocesanas y ayudar en sus necesidades más vitales como es la promoción vocacional.

$10^{\mathrm{a}} \mathrm{El}$ énfasis vocacional ha de estar presente en una evangelización corresponsable. Dentro de la evangelización existe una tarea a tener muy presente no solamente por los sacerdotes sino también por los catequistas, los profesores de Religión y por los padres de los alumnos. A todos les compete acompañar a niños y jóvenes en el descubrimiento y seguimiento de su vocación mediante una adecuada formación y vivencia cristiana.

$11^{\text {a }}$ Cristo es el centro de toda vocación y seguir a Cristo suele ser una de las principales motivaciones del que opta por el sacerdocio. De aquí que no se entienda una Pastoral vocacional si no es en el gran contexto teológico centrado en la figura de Cristo. Por ello la figura de Cristo ocupa un puesto prioritario en la Pastoral vocacional que toma muchos criterios del mensaje cristiano.

$12^{\text {a }}$ Una de las tareas vocacionales de la Pastoral litúrgico-sacramental es lograr que el joven experimente la presencia de Cristo en toda celebración litúrgica, especialmente en la Eucaristía dominical. 
De aquí la importancia de las orientaciones y normas para que brote en los jóvenes el deseo de poder un día representar a Cristo en el altar celebrando la Palabra y el Sacrificio eucarístico. Habrá que evitar la dedicación exclusiva del sacerdote a las tareas del culto o las celebraciones litúrgicas rutinarias, comerciales, folklóricas, muy tradicionales y sin atractivo para la juventud.

$13^{\mathrm{a}}$ Servir a los hermanos es una de las motivaciones de quien desea configurarse con Cristo buen Pastor y vivir la caridad pastoral. Por ello la Pastoral vocacional ha de tener muy presente las exigencias radicales de la caridad fraterna. El amor universal del sacerdote pastor tiene como preferidos a los más necesitados, a los pobres. Para seguir el ejemplo de Cristo y de la Iglesia el sacerdote debe concretar un compromiso con los pobres que arranca del conocimiento de la realidad, evita la injusticia, cumple con las exigencias de la justicia social y termina con el testimonio de una caridad social que se acomoda al Evangelio actualizado.

$14^{\mathrm{a}}$. El testimonio de la caridad radical necesita unas manifestaciones concretas que sean convincentes y motivadoras para quien se plantea la vocación sacerdotal. Entre las exigencias hay que enumerar la comunicación de los bienes de todo tipo hasta poder compartir con los pobres los bienes necesarios. Por lo menos destinar el $1 \%$ de los fondos que se gestionan para cooperar con instituciones socio-caritativas. Como ejemplo de buenos pastores, "los presbíteros aportarán al fondo común diocesano, una parte de sus propios ingresos, según lo establecido en la diócesis".

$15^{\mathrm{a}}$ La Pastoral vocacional dentro de un análisis de la praxis cristiana, de una eclesiología dinámica, de una evangelización con enfoque vocacional, de una Liturgia capaz de atraer a Cristo y de una Pastoral social enfocada al testimonio de una caridad radical, se convierte en la Pastoral vocacional contextual y corresponsable. 